\title{
PRZEGLĄD BADAŃ DOTYCZĄCYCH PRAKTYCZNEGO WYKORZYSTANIA METOD SZACOWANIA KOSZTU KAPITAŁU W GOSPODARKACH ROZWINIĘTYCH I ROZWIJAJĄCYCH SIE
}

\author{
Tomasz Pawlonka
}

Katedra Finansów

Szkoła Główna Gospodarstwa Wiejskiego w Warszawie

\begin{abstract}
Abstrakt. Główny cel działania przedsiębiorstw, zwiększanie wartości dla właścicieli, wymaga świadomości w zakresie wysokości kosztu kapitału. Funkcjonujące w teorii finansów i w praktyce gospodarczej metody szacowania kosztu kapitału nadal pozostają dyskusyjne. Nie są one transparentne dla wszystkich przedsiębiorstw i dla wszystkich gospodarek. Celem artykułu jest przedstawienie opinii praktyków oraz zestawienie jej z poglądami teoretycznymi w zakresie rzeczywistej kalkulacji kosztu kapitału. Szczególny nacisk położono na model CAPM oraz na poszczególne parametry tego modelu.
\end{abstract}

Słowa kluczowe: koszt kapitału, CAPM, stopa wolna od ryzyka, rynkowa stopa zwrotu

\section{WSTĘP}

Obserwowane współcześnie zainteresowanie tematyką kosztu i struktury kapitału oraz ich wpływu na wartość przedsiębiorstwa zaowocowało ożywioną dyskusją na temat metodycznego podejścia do tego zagadnienia. Dotychczasowy rozwój teorii finansów w tym zakresie dał solidne podstawy w postaci propozycji modeli oraz wielu innych technik szacowania kosztu kapitału. Jak zauważa Ferling dotychczasowe badania prowadzone w USA sugerują rosnące zainteresowanie wśród analityków, inwestorów oraz dyrektorów finansowych tematyką struktury 
i kosztu kapitału oraz polityką dywidendową firm [Ferling 1994]. Zdaniem Copelanda, Westona, Bughina i Stewarta zagadnienia te stanowią współcześnie jedno z najcenniejszych kryteriów oceny działalności przedsiębiorstw, na co wskazuje rozwój koncepcji zarządzania przez wartość dla właścicieli. Wiele dyskusji naukowych dotyczących metodyki szacowania kosztu kapitału nie pozwoliło dotychczas na osiągnięcie konsensusu w tej kwestii. Nadal nie wypracowano uniwersalnej i najlepszej, ani nawet w pełni akceptowalnej metody, choć nikt nie kwestionuje konieczności jej stworzenia i wagi kosztu kapitału w strategicznym zarządzaniu finansami przedsiębiorstw [Stewart 1985, Bughin i Copeland 1997, Copeland i Weston 1998]. Podejmowana dyskusja naukowa w pewnym punkcie spotyka się z podejściem praktycznym. W prowadzonej dyskusji naukowej nie można zapomnieć o poglądach praktyków na zagadnienie kosztu i struktury kapitału. Głównym celem artykułu jest uzupełnienie rozważań teoretycznych o przegląd badań światowych i krajowych w zakresie skali pomiaru kosztu kapitału, w szczególności w kwestii dotyczącej potrzeby, sposobów (metodyki) oraz sensu szacowania kosztu kapitału przez przedsiębiorstwa. Sformułowane wnioski i poglądy stanowią pewne kompendium wiedzy mogące być cennym źródłem informacji na etapie szacowania kosztu kapitału.

\section{WYNIKI BADAŃ Z GOSPODAREK ROZWINIĘTYCH}

Istotny wkład w dostrzeżenie głosu praktyków w kwestii metodyki szacowania kosztu kapitału oraz znaczenia struktury kapitału w realnym biznesie wniosły badania zespołu Brunera [Bruner i in. 1998]. Badacze przeprowadzili badanie ankietowe na niereprezentatywnej próbie składającej się z 27 przedsiębiorstw uwzględnionych na liście Creating World-Class Financial Management: Strategies of 50 leading companies [Business International Corporation 1997]. Próbę wzbogacono ponadto opiniami doradców finansowych oraz porównano ze funkcjonującymi w dyscyplinie finansów teoriami. Wnioski z badania wskazują jednoznacznie, że analiza zdyskontowanych strumieni pieniężnych (DCF) stanowi dominujące narzędzie stosowane przy wycenie projektów inwestycyjnych i w tym celu zarówno dyrektorzy finansowi, jak i doradcy finansowi stosują stopę dyskontową odzwierciedlającą koszt kapitału. Badanie to dowiodło również, że metoda CAPM stanowi podstawowe narzędzie stosowane powszechnie przy wycenie kosztu kapitału własnego (81\% dyrektorów finansowych i 80\% doradców). Ankietowani zgodzili się także z ogólną postacią modelu CAPM uwzględniającą w swojej konstrukcji stopę wolną od ryzyka, współczynnik $\beta$ oraz premię z tytułu ryzyka rynkowego. Znaczne rozbieżności pojawiły się natomiast przy próbie określenia szczegółowej metodyki przy ustalaniu poszczególnych parametrów modelu CAPM. Już na etapie określenia podejścia przy ustaleniu parametru $\beta$ responden- 
ci wskazali, że nie robią tego samodzielnie, tylko korzystają z ogólnodostępnych, opublikowanych danych. Co niepokojące, pogląd taki wyraziło aż 52\% dyrektorów finansowych oraz $40 \%$ doradców. Na samodzielne szacowania $\beta$ wskazało jedynie $30 \%$ dyrektorów oraz $20 \%$ doradców. Wniosek z powyższego pytania ankietowego z pewnością nie możne napawać optymizmem, bowiem wskazuje na znikomą samodzielność dyrektorów, którzy zwracają się o pomoc do doradców finansowych. Ci z kolei również nie szacują parametrów indywidualnie, a jedynie posługują się aż w 70\% wtórnymi miarami $\beta$. Posługiwanie się „gotowymi” miarami niektórych wskaźników jest oczywiście zgodnie z poglądami proponowanymi w literaturze przedmiotu i jest podejściem akceptowalnym. Niemniej jednak bazowanie na danych wtórnych nie pozwala na opracowanie własnej metodyki, lepiej dopasowanej do specyfiki prowadzonej działalności. Podejście takie generuje ponadto zwiększone ryzyko modelu związane z powielaniem pewnych schematów, być może nie zawsze bazujących na rzeczywistych danych. Opracowanie jasnych reguł i zasad postępowania oraz uniwersalnych standardów w doborze poszczególnych parametrów modelu CAPM pozwoliłoby na zwiększenie samodzielności szacunków wśród dyrektorów, doradców finansowych oraz innych grup zawodowych. Pewnym odzwierciedleniem braku jasnych reguł i standardów w zakresie doboru parametrów do modelu CAPM jest oszacowanie stopy wolnej od ryzyka. Wynik badania przedstawiony na rysunku wskazuje na brak jednomyślności również w tym zakresie.

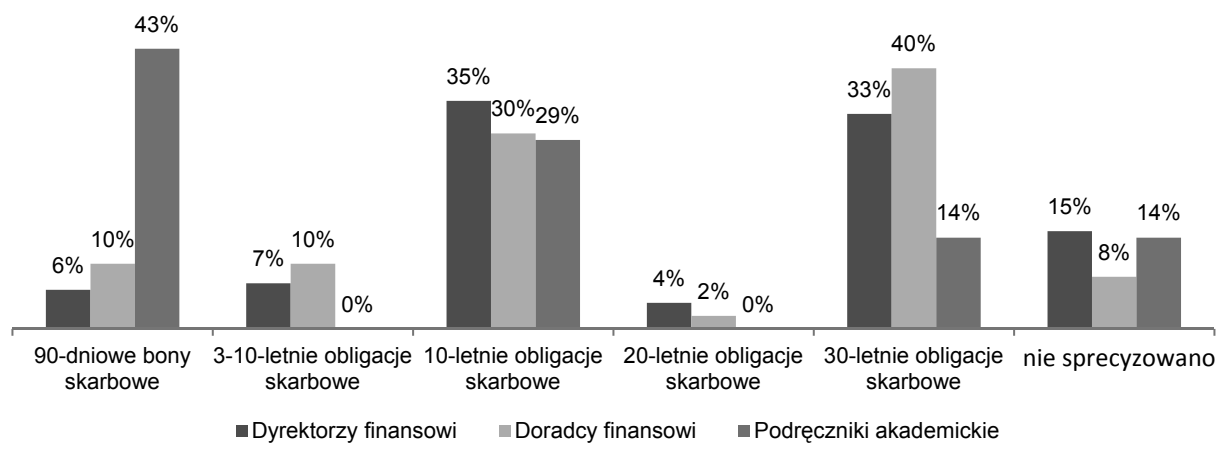

RYSUNEK. Szacowanie stopy wolnej od ryzyka zdaniem praktyków i teorii

Źródło: Opracowanie własne na podstawie Bruner i in. [1998].

Pewną charakterystyczną różnicą w podejściu praktyki i teorii była wyraźna rozbieżność w terminach zapadalności instrumentu traktowanego jako stopa wolna od ryzyka. 0 ile podręczniki akademickie sugerują posługiwanie się 90-dniowymi bonami skarbowymi (43\%), o tyle dyrektorzy finansowi i doradcy finansowi preferują instrumenty o wyraźnie dłuższym terminie zapadalności (średnio 8\% wskazań na 90-dniowe bony skarbowe). Zauważyć należy, że na rynku amerykań- 
skim różnica w rentowności tych instrumentów wynosi około 150 punktów bazowych, co przy aplikacji metody CAPM do realnego biznesu wskazuje na diametralnie różne wyniki. Dyrektorzy finansowi, jako stopę wolną od ryzyka najczęściej przyjmują rentowność 10-letnich obligacji skarbowych (35\%), ale równie często rentowność 30-letnich obligacji skarbowych (33\%). Doradcy finansowi z kolei, odwrotnie niż dyrektorzy, preferują rentowność 30-letnich obligacji skarbowych (40\%) oraz 10-letnich obligacji skarbowych (30\%). Można zatem stwierdzić, że wśród praktyków dominujący był pogląd, że najlepszą stopę wolną od ryzyka pozwala uzyskać rentowność obligacji o 30-letnim terminie zapadalności (36,5\%), wobec 32,5\% wskazań na rentowność instrumentów 10-letnich. Jednocześnie, uwzględniając preferencje całej próby badawczej i ustalając średnią arytmetyczną jako miarę obiektywną dla danej grupy, stwierdzić należy, że zdaniem $31 \%$ ankietowanych to obligacje o 10-letnim horyzoncie są najlepszą miarą stopy wolnej od ryzyka. Na obligacje 30-letnie wskazało $29 \%$ respondentów, a 90-dniowe bony skarbowe wybrało $20 \%$ ankietowanych. Nie mniej jednak około $72 \%$ praktyków wskazuje na wykorzystanie instrumentów o 10-letnim i dłuższym terminie zapadalności, podczas gdy teoria finansów sugeruje takie podejście jedynie w 43\% przypadków. Badanie to potwierdziło zatem, że nawet na rozwiniętym rynku, jakim bez wątpienia jest rynek amerykański, nie istnieją jednoznaczne instrukcje dotyczące metodyki szacowania kosztu kapitału własnego. Jednocześnie dodać należy, że ankietowani, wybierając rentowność 10-letnich obligacji skarbowych, sugerowali, że to właśnie ten horyzont czasowy jest najbardziej odpowiedni do horyzontu czasowego przedsięwzięcia inwestycyjnego.

O ile ustalenie metodyki wyboru stopy wolnej od ryzyka wskazało na pewną rozbieżność między teorią i praktyką (oraz częściowo między samymi praktykami), o tyle próba kwantyfikacji metodyki wyboru premii z tytułu ryzyka rynkowego wskazuje na absolutny brak jednomyślności w tym zakresie. Zdaniem 48\% dyrektorów i $60 \%$ doradców wartość ta można zostać przyjęta odgórnie jako pewien stały parametr. Z poglądem takim nie zgadza się natomiast teoria, która sugeruje samodzielnie obliczenie premii z tytułu ryzyka rynkowego jako średniej arytmetycznej (71\%) bądź też geometrycznej (15\%). Wśród praktyków koncepcja ta nie cieszy się zbytnią popularnością. Jedynie 6\% dyrektorów finansowych posługuje się średnią arytmetyczną i średnią geometryczną. Wśród doradców proporcja ta wynosi odpowiednio $10 \%$ do $10 \%$. Jednocześnie, aż 18\% dyrektorów zwraca się z prośbą o ustalenie wartości stopy z tytułu ryzyka rynkowego do zewnętrznych ekspertów. Jako że wybór pewnej stałej wartości z tytułu ryzyka rynkowego cieszy się największą popularnością wśród ankietowanych, poproszono ich o określenie wysokości tejże stopy. Zdaniem dyrektorów finansowych jest to wartość na poziomie 5-6\% (37\% ankietowanych), bądź też 4,0-4,5\% (11\%). Doradcy szacują premię z tytułu ryzyka rynkowego na wyraźnie wyższym poziomie równym 7,0-7,5\% (50\%). Jedynie 10\% doradców uważa, że wartość ta oscyluje wokół 5\%. 
Pewne rozbieżności między teorią a praktyką zaobserwowano również w przypadku ewentualnych korekt kosztu kapitału w odniesieniu do ryzyka towarzyszącego pojedynczym inwestycjom. 0 ile $86 \%$ podręczników akademickich sugeruje tego typu działanie poprzez korektę współczynnika $\beta$, o tyle wśród praktyków jedynie $42,5 \%$ ankietowanych decyduje się na taki krok. Jednocześnie $51 \%$ dyrektorów finansowych wskazało, że szacunki dotyczące kosztu kapitału mają inne, poza oceną projektów inwestycyjnych, znaczenie. Z pewnością wynik ten wskazuje na fundamentalne i być może rosnące w czasie znaczenie kalkulacji kosztu kapitału w zarządzaniu strategicznym finansami przedsiębiorstwa.

Wnioski z przeprowadzonego badania pozwalają dostrzeżec wiele zgodności występujących między praktyką a teorią finansów. Jednocześnie w przypadku nieostrych i niejednoznacznych poglądów teoretycznych wyraźne są pewne trudności w przyjęciu jednomyślnego stanowiska wśród praktyków. Podkreślić należy ponadto, że sytuacja ta ma miejsce na rynku amerykańskim, a zatem na rynku o wieloletnich tradycjach i rozbudowanej strukturze. Spodziewać się można, że na rynkach mniej rozwiniętych oraz rozwijających się pewne rozbieżności między teorią a praktyką oraz między opiniami samych praktyków mogą się nasilić. Badanie to wskazuje również na konieczność dalszej ewolucji teorii finansów w celu precyzyjniejszego określenia metodyki doboru poszczególnych parametrów do szacowania kosztu kapitału własnego.

Podobne badania przeprowadzone zostały również w Wielkiej Brytanii, a ich autorami byli Al-Ali i Arkwright [2000]. Badacze skierowali ankiety do 450 największych, pod względem przychodów ze sprzedaży, brytyjskich przedsiębiorstw. Ostatecznie uzyskano 74 kompletne odpowiedzi. Badanie to również nie może zostać uznane za reprezentatywne, ale mimo to niesie ze sobą cenne walory poznawcze. Pozwala ono na postawienie bardzo ogólnej diagnozy, potwierdzenie której dodatkowymi badaniami uzupełniającymi na innych próbach badawczych daje szansę na skonstruowanie wiarygodnych hipotez. W badaniu stwierdzono, że ponad 93\% przedsiębiorstw regularnie określa koszt kapitału, który wykorzystywany jest jako stopa dyskontowa w ocenie rentowności projektów inwestycyjnych. Szacunki te dokonywane są głównie przy wykorzystaniu modelu CAPM (85\%), przy czym dla 69\% ankietowanych była to jedyna metoda określania kosztu kapitału. Równocześnie model zdyskontowanych dywidend wykorzystywany jest, niekiedy wspomagająco, przez $21 \%$ ankietowanych. Wnioski z niniejszego badania w zakresie popularności modelu CAPM oraz skali wykorzystania kosztu kapitału w bieżącej działalności przedsiębiorstw wydają się być zbieżne z wnioskami z badań zespołu Brunera. Respondenci wyrazili również swój pogląd dotyczący parametrów niezbędnych do oszacowania kosztu kapitału przy wykorzystaniu modelu CAPM. W określeniu wysokości stopy zwrotu wolnej od ryzyka aż 58\% przedsiębiorstw posługuje się rentownością 10-letnich obligacji skarbo- 
wych. Jedynie $20 \%$ respondentów szacuje ten parametr na bazie rentowności 90-letnich bonów skarbowych. Około $22 \%$ przedsiębiorstw wykorzystuje w tym celu obligacje skarbowe o innym terminie zapadalności (dłuższym bądź krótszym niż 10 lat). W tym zakresie wyniki obu badań również wydają się być zbieżne, choć nadal brak w nich jednomyślnego podejście i wyraźnej uniwersalnej metodyki postępowania. W odróżnieniu od wyników badań zespołu Brunera, ankietowani wskazali w $82 \%$ przypadków, że premię za ryzyko rynkowe obliczają jako średnią arytmetyczną na bazie historycznych notowań. Pogląd ten zbieżny jest z teorią finansów. Jednocześnie 18\% przedsiębiorstw wskazało, że parametr ten szacowany jest przez zewnętrznych ekspertów-konsultantów. Sama wysokość premii za ryzyko rynkowe, po uśrednieniu, oscyluje wokół 5\%, co również jest zbieżne z wynikami z poprzedniego badania. Zauważyć należy, że w przypadku rynku brytyjskiego, analogicznie jak w przypadku rynku amerykańskiego, wartość premii za ryzyko rynkowe odbiega od wartości sugerowanych w literaturze przedmiotu (6,0-8,5\%) [Brealey i Myers 1991]. W odniesieniu do parametru $\beta$ aż $76 \%$ ankietowanych przyznało się do korzystania z gotowych miar publikowanych przez różne agencje. Jedynie $24 \%$ przedsiębiorstw szacuje ten parametr samodzielnie. W szacowaniu kosztu kapitału obcego 80\% respondentów uwzględnia mechanizm tarczy podatkowej, a jedynie $15 \%$ kalkuluje go w wersji „przed opodatkowaniem". Prowadzona wycena projektów inwestycyjnych w opinii $51 \%$ przedsiębiorstw prowadzona jest w ujęciu realnym, z kolei $42 \%$ wykorzystuje $\mathrm{w}$ tym celu podejście bazujące na wartościach nominalnych. Jednocześnie do wyceny projektów aż $62 \%$ respondentów wskazało na wykonywanie korekt w wysokości stopy dyskontowej związanych ze specyfiką przedsięwzięcia. Wyniki przeprowadzonego badania wydają się zatem potwierdzać wnioski z badań zespołu Brunera. Jedyna zauważalna i istotna różnica związana jest głównie z podejściem do metody kalkulacji premii z tytułu ryzyka rynkowego, choć sama wartość premii jest zbieżna w obydwu badaniach. Badanie to, po raz kolejny, wskazuje na pewne trudności w ustaleniu jednolitej procedury szacowania kosztu kapitału, co stwarza „lukę do zagospodarowania” dla współczesnej teorii finansów.

\section{WYNIKI BADAŃ Z GOSPODAREK ROZWIJAJĄCYCH SIĘ}

Współcześnie oczekuje się również prowadzenia analogicznych badań na rynkach rozwijających się. Wyzwaniu temu sprostała firma Pricewaterhouse Coopers, która przeprowadziła badanie ankietowe na rynku indyjskim. Ten niezwykle dynamicznie rozwijający się rynek przechodzi w ostatnich latach gruntowne przemiany. Zainteresowanie ze strony zewnętrznych inwestorów obliguje rodzimych przedsiębiorców do dostosowania standardów w zakresie zarządzania finansami przedsiębiorstw do standardów obowiązujących w krajach wysokorozwiniętych 
[Sanjeev 2012, Agarwal 2013]. Badaniem objęto przedstawicieli 34 wiodących w Indiach firm i skierowano do nich pytania ankietowe dotyczące możliwości, sposobu i potrzeby szacowania kosztu kapitału [Giri i Sivala 2013]. Wśród respondentów aż 90\% zadeklarowało posługiwanie się modelem CAPM przy wycenie kosztu kapitału własnego, jednakże aż $75 \%$ z nich wskazało, że szacowanie parametru $\beta$ stanowiącego sedno całego modelu dokonywane jest jedynie na podstawie danych pochodzących z rynku indyjskiego, jest nieprecyzyjne i nie uwzględnia wszystkich czynników wpływających w rzeczywistości na koszt kapitału własnego. Spośród ankietowanych wykorzystujących w analizach model CAPM aż 67\% wskazało, że ostateczny rezultat koryguje o premie i dyskonta. Do najczęściej wymienianych motywów tworzenia korekt zaliczyć można: dominującą pozycję w danej branży, trwałość (stabilność) zysków oraz jakość zarządzania. Sam współczynnik $\beta$ szacowany jest najczęściej na podstawie danych tygodniowych w okresach trzyletnich (44\% respondentów). Respondenci wskazali bowiem, że zachodzące dynamicznie procesy restrukturyzacyjne w gospodarce indyjskiej, w powiązaniu ze zmianami w samych przedsiębiorstwach, sprawiły, że dane z krótszych okresów stanowią znacznie lepszy wyznacznik profilu ryzyka firm. Premia za ryzyko rynkowe szacowana jest przez 91\% przedsiębiorstw na podstawie gotowych, ogólnodostępnych danych dla rynku indyjskiego. Spośród analityków i inwestorów pogląd ten podziela aż 63\% respondentów. Jedynie 37\% analityków decyduje się na samodzielnie szacowanie premii z tytułu ryzyka rynkowego. Ankietowani, tłumacząc motywy swoich decyzji, wskazali, że w szacowanie premii z tytułu ryzyka rynkowego jest niezwykle trudne z uwagi na zbyt krótkie szeregi czasowe w odniesieniu do danych historycznych pochodzących z rynku kapitałowego oraz brak jasnych procedur. Jednocześnie respondenci wskazali prawie jednomyślnie, że najlepszym wyznacznikiem stopy wolnej od ryzyka, jest rentowność 10-letnich obligacji skarbowych (89\%). Badanie to wskazało również pewne trudności towarzyszące wschodzącym gospodarkom. Problemy i niejasności zdiagnozowane na rynkach rozwiniętych, tj. brytyjski czy amerykański, nasilają się na rynkach rozwijających się z uwagi na brak odpowiednich danych oraz konieczność korygowania ostatecznych szacunków o dodatkowe, często subiektywne premie i dyskonta. Posługiwanie się trzyletnią głębokością retrospekcji przy szacowaniu współczynnika $\beta$ dla rynku rozwijającego się może $\mathrm{w}$ rzeczywistości zbyt silnie oddziaływać na jego wartość. W rezultacie delikatne wahania koniunktury mogą powodować jego gwałtowany przyrost/spadek. Otwarte pozostaje zatem pytanie o stabilność współczynników $\beta$ w czasie. Jednocześnie metodyka szacowania współczynników $\beta$ na podstawie trzyletnich obserwacji nie jest obca praktykom (choć stosunkowo rzadka, bowiem częściej stosuje się cztero- i pięcioletni okres badań), czego dowodzi działalność agencji takich jak Bloomberg. Działają one na rynkach kapitałowych o wieloletnich tradycjach, które charakteryzują się przy- 
najmniej względną stabilnością, a krótki horyzont obserwacji przy szacowaniu parametru $\beta$ może zostać zneutralizowany głębszą retrospekcją przy szacowaniu premii z tytułu ryzyka rynkowego, czego zazwyczaj nie mogą zrobić gospodarki rozwijające się. W rezultacie rynki rozwijające się zmuszone są do uwzględniania w swoich szacunkach gotowych danych, przygotowywanych często z zastosowaniem skorygowanych wartości parametrów obliczonych dla warunków rynków rozwiniętych. Z pewnością stwierdzić można, że kraje rozwijające się potrzebują czasu, aby uzyskać warsztat niezbędny do bardziej wiarygodnych analiz.

\section{WYNIKI BADAŃ W POLSCE}

Analogiczne, bardzo rozbudowane badanie dotyczące metodyki szacowania kosztu kapitału w Polsce przeprowadziła Byrka-Kita. Udział w nim wzięło 69 przedsiębiorstw, z czego 11 było instytucjami finansowymi. Z pewnością zestawienie niniejszych badań z wytycznymi teorii finansów oraz z wnioskami z badań z rynków rozwiniętych i rozwijających się stanowi szansę na określenie pewnych barier i trudności szacowania kosztu kapitału na krajowym rynku oraz wskazanie stopnia rozwoju i kultury w zakresie rozumienia i umiejętności praktycznego stosowania, nie zawsze w pełni skwantyfikowanej, metodyki szacowania kosztu kapitału [Byrka-Kita 2008].

Pierwszym pytaniem stanowiącym niejako rozeznanie w znaczeniu kosztu kapitału w budowaniu wartości przedsiębiorstw było określenie głównego czynnika determinującego ową wartość. Respondenci wskazali w 63,8\% przypadków, że czynnikiem głównym jest marża zysku na poziomie operacyjnym. Jednocześnie 13,0\% ankietowanych stwierdziło, że jest nim stopa wzrostu sprzedaży. Jedynie 5,8\% respondentów dostrzegło w koszcie kapitału główny czynnik wzrostu wartości przedsiębiorstw. Wyniki te z pewnością nie mogą dziwić i zaskakiwać, bowiem wskazują na pragmatyczne podejście. Jednocześnie zauważyć należy, że przedsiębiorcy przynajmniej w pewnym stopniu dostrzegają znaczenie kosztu kapitału w budowaniu wartości przedsiębiorstw. Jednocześnie 62,3\% respondentów wskazało, że prowadzi regularnie szacunki dotyczące wyceny kosztu kapitału w swoim przedsiębiorstwie. W przypadku instytucji finansowych wyceny takiej dokonuje $100 \%$ respondentów, robiąc to samodzielnie. Przedsiębiorstwa sektora niefinansowego wskazały, że w 55,2\% dokonują wyceny kosztu kapitału, przy czym w 34,5\% wyceny tej dokonują samodzielnie. Potwierdzeniem dominującej metodyki wyceny kosztu kapitału jest wiodąca rola modelu CAPM. Na wykorzystanie modelu wyceny aktywów kapitałowych wskazało 40,6\% respondentów. Drugą pod względem popularności metodą z 30,0\% wskazań była metoda ekspercka, która w swojej konstrukcji również nie wyklucza stosowania w całości bądź też częściowo modelu CAPM. 
Niemniej jednak sama budowa modelu CAPM i dobór poszczególnych jego parametrów jest równie dyskusyjny w przypadku polskiej gospodarki, jak i gospodarek rozwiniętych. Brak jasnych reguł i procedur potwierdza się m.in. dyskusją dotyczącą określenia instrumentu bazowego do oszacowania stopy wolnej od ryzyka. W przypadku niniejszego badania zaobserwowano znacznie większą rozbieżność w stosunku do określenia stopy wolnej od ryzyka niż w krajach wysokorozwiniętych, choć i w ich przypadku nie było wyraźnej jednomyślności. Jako instrument bazowy w Polsce równie często wykorzystywano rentowność 90-dniowych bonów skarbowych $(24,6 \%)$, jak rentowność 10-letnich obligacji skarbowych $(24,6 \%)$. Z pewnością stwierdzić można, że w polskiej gospodarce brakuje jasnego sygnału świadczącego o tym, który z instrumentów finansowych stanowi najlepszy wyznacznik stopy wolnej od ryzyka. W krajach rozwiniętych, choć kwestia ta również nie jest jasno sprecyzowana, występuje znacznie większa zgodność dotycząca dominującej roli 10-letnich obligacji skarbowych. Jednocześnie podejście towarzyszące polskim przedsiębiorstwom w większym stopniu nawiązuje do wytycznych zawartych w teorii finansów.

W przypadku szacunków dotyczących współczynnika $\beta, 11,6 \%$ respondentów wskazało na wykorzystanie notowań giełdowych własnego przedsiębiorstwa. Taki sam udział wskazań dotyczył współczynników $\beta$ podobnych spółek notowanych na Giełdzie Papierów Wartościowych w Warszawie. Jedynie 7,2\% respondentów korzystało $\mathrm{w}$ tym celu ze współczynników $\beta$ podobnych spółek notowanych na rynkach zagranicznych. Znaczna cześć respondentów wskazała na wykorzystanie metody eksperckiej do określenia współczynnika $\beta(16 \%)$. Metoda ta jest również głównie stosowana $\mathrm{w}$ przedsiębiorstwach sektora niefinansowego $(17,2 \%$ wskazań). Dostrzec należy, że posługiwanie się metodą ekspercką bez stosowania danych finansowych może powodować znaczny subiektywizm prowadzonej wyceny, co w rezultacie może rzutować na jej wiarygodność. Jednocześnie brak skonkretyzowanych odpowiedzi na temat samych ekspertów oraz procedury prowadzonych szacunków może wskazywać na powierzchowną znajomość modelu CAPM wśród ankietowanych.

Określenie głębokości retrospekcji przy ustalaniu parametrów modelu CAPM pozwoliło ustalić, że respondenci posługiwali się głównie miesięcznymi stopami zwrotu (13\% wskazań). Instytucje finansowe równie często jak miesięczne stopy zwrotu wykorzystywały tygodniowe stopy zwrotu $(18,2 \%)$. Stosowanie danych tygodniowych najczęściej związane było z pięcioletnim horyzontem prowadzonych badań. Przy wykorzystaniu danych miesięcznych posługiwano się natomiast trzyletnim okresem danych historycznych. Podejście to jest zgodne zatem ze standardami wykorzystywanymi przez agencje na rynkach rozwiniętych.

Metodyka wyznaczania premii za ryzyko rynkowe w dominującym stopniu wykorzystywano metodę ekspercką (24,6\% wskazań), przy czym w instytucjach 
finansowych jej udział wyniósł 63,6\% wobec 17,2\% w przedsiębiorstwach niefinansowych. Premię za ryzyko rynkowe wyznaczone na podstawie rynkowych oczekiwań dotyczących przyszłych stóp zwrotu szacuje 17,4\% respondentów. Jedynie $17,3 \%$ ankietowanych deklarowało, że posługuje się danymi historycznymi, przy czym $7,2 \%$ danych pochodziło z rynku polskiego, a 10,1\% z innych rynków rozwiniętych. Jednocześnie $8,7 \%$ respondentów przy wyznaczaniu premii za ryzyko rynkowe bazuje na opiniach prezentowanych w pracach uznanych autorytetów w dziedzinie finansów. Badanie to pokazuje zatem, że w odróżnieniu od rynku indyjskiego polskie przedsiębiorstwa podejmują próby samodzielnego określenia premii za ryzyko rynkowe. Spodziewać się można, że dominujący udział metody eksperckiej w prowadzonych szacunkach związany jest $\mathrm{z}$ dokonywaniem przez przedsiębiorców wielu korekt uwzględniających premie i dyskonta z tytułu wybranych czynników. Z pewnością podejście to zasługuje na wyróżnienie, choć pamiętać należy, że poszczególne korekty często obarczone są wysokim stopniem subiektywizmu. Próba określenia wysokości premii za ryzyko rynkowe wskazuje na rezultat zbliżony do rynków rozwiniętych i oscyluje wokół 5\%.

Instytucje finansowe oszacowały koszt kapitału obcego na około 9-9,5\%. $\mathrm{W}$ przedsiębiorstwach sektora niefinansowego koszt ten określono w przedziale 7-8\%. Dominującym motywem wykorzystania długu w finansowaniu działalności przedsiębiorstw, zdaniem $66,7 \%$ respondentów, były niewystarczające środki własne. Na chęć wykorzystania mechanizmu dźwigni finansowej wskazało 40,6\% ankietowanych. Korzyści płynące z mechanizmu tarczy podatkowej dostrzegało $26,1 \%$ ankietowanych. Zdaniem ankietowanych głównym czynnikiem determinującym wielkość kosztu długu jest polityka NBP (42\% wskazań). Zdaniem 24,6\% respondentów to ryzyko biznesu stanowi czynnik kluczowy determinujący wielkość kosztu kapitału obcego. Równie często $(14,5 \%)$ wskazywano inflację oraz prognozowaną inflację jako czynniki wpływające na wielkość bieżącego i przyszłego kosztu długu. Zaskakująco nisko oceniono znaczenie bieżącej struktury kapitału (jedynie 2,9\% wskazań). Podejście takie sugerować może, że bez względu na poziom zadłużenia przedsiębiorstwa koszt kapitału obcego i tak będzie stały. Spostrzeżenie to może sugerować, że potencjalni kredytodawcy nie przykładają większej wagi do ryzyka finansowego towarzyszącego danemu przedsiębiorstwu. Jednocześnie dostrzec należy, że ryzyko to mogło zostać w opinii przedsiębiorców wkalkulowane w tzw. ryzyko biznesu. Stosunkowo niewielkie znaczenie przypisano również historycznym i prognozowanym przypływom pieniężnym $(5,8 \%)$ oraz jakości zarządzania (5,8\%), przy czym czynniki te mają większe znaczenie dla instytucji finansowych $(18,2 \%)$ niż dla przedsiębiorstw niefinansowych $(3,4 \%)$.

Dalsza część badania związana była z identyfikacją znaczenia, roli i praktycznego kształtowania struktury kapitału w przedsiębiorstwa. Byrka-Kita próbowała zatem uzyskać odpowiedź na pytanie, czy optymalna struktura kapitału w ogóle 
istnieje, a jeśli tak, to czy jest w rzeczywistości ustalana przez przedsiębiorstwa i na jakim poziomie się znajduje. Respondenci wskazali, że bieżący udział długu w finansowaniu majątku przedsiębiorstw wynosi około 26\%, przy czym jego optymalny udział jest równy 33,5\%. Jednocześnie 62,1\% ankietowanych przyznało, że w swoim przedsiębiorstwie nie ma ustalonej docelowej, optymalnej struktury kapitału. Wśród 36,2\% przedsiębiorstw posiadających ustaloną, optymalną strukturę kapitału udział długu w strukturze pasywów wynosi 36,82\%. Przedsiębiorstwa te jako główny motyw ustalania docelowej struktury kapitału wskazały na ryzyko biznesu z uwzględnieniem bieżącej struktury kapitałowej $(30,4 \%)$ oraz tendencje panujące w branży $(17,4 \%)$. Jednocześnie 17,4\% respondentów wskazało na chęć wykorzystania mechanizmu dźwigni finansowej.

\section{WNIOSKI I DALSZE KIERUNKI BADAŃ}

Przedstawione badania wskazały zatem na brak uniwersalnej metodyki szacowania kosztu kapitału zarówno na rynkach rozwiniętych, jak i na rynkach rozwijających się. Pogląd ten potwierdzony został ponadto opiniami praktyków jak i wytycznych wynikających z teorii finansów. Dostrzeżono również pewną rozbieżność występującą między teorią a praktyką, w szczególności w odniesieniu do szacowania stopy wolnej od ryzyka. Jednocześnie brak uniwersalnych procedur w modelu CAPM sprawia, że na rynkach rozwijających się trudności związane z szacowaniem kosztu kapitału dodatkowo nasilają się. Bezsprzecznie stwierdzono, że model CAPM stanowi mimo wszystko podstawowe narzędzie wyceny kosztu kapitału.

Badania w Polsce wskazały, że nie wszyscy przedsiębiorcy podejmują trud związany z szacowaniem kosztu kapitału. W tym zakresie polscy respondenci w dość znacznym stopniu odbiegają od przedsiębiorców z rynków rozwiniętych, dla których proces szacowania kosztu kapitału jest typowym i standardowym elementem procesu zarządzania finansami swoich przedsiębiorstw. Co więcej, wśród krajowych respondentów dostrzegalne są zwiększone trudności związane z metodyką prowadzonych obliczeń. Większość kalkulacji związanych z określeniem wartości przedsiębiorstwa oraz kosztu kapitału ma charakter subiektywny, arbitralny. Znaczna część obliczeń prowadzona jest również przez zewnętrznych ekspertów. W rezultacie poziom świadomości przedsiębiorców w zakresie metodyki szacowania kosztu kapitału oraz określania wartości przedsiębiorstwa nie jest wysoki. Popularność najbardziej rozpowszechnionego na świecie modelu CAPM również nie jest tak duża wśród polskich przedsiębiorców jak wśród zarządzających finansami przedsiębiorstw na rynkach rozwiniętych. Z pewnością w znacznym stopniu winna temu stanowi rzeczy jest znikoma dostępność mate- 
riału badawczego mogącego stanowić wiarygodne źródło informacji o podstawowych parametrach modelu. Krótka historia polskiego rynku kapitałowego oraz znaczny poziom wahań notowań poszczególnych indeksów oraz spółek wchodzących w ich skład znacząco utrudniają prowadzenie prognoz i szacunków na tej podstawie. Wśród polskich przedsiębiorców posługujących się modelem CAPM przyjmowana metodyka oraz dobór parametrów modelu nie odbiega od światowych wzorców, choć sami respondenci nie mają pełnego przekonania co do przyjmowanej metodyki. Przeprowadzone badanie wskazuje zatem na możliwość kontynuowania dyskusji dotyczącej praktycznego podejścia w zakresie szacowania kosztu kapitału na rynkach rozwijających się.

\section{Spis literatury}

AGARWAL M. 2013: The opportunity and challenge of India's infrastructure, Gridlines, Pricewaterhouse Coopers, Summer, 1-9.

Al-ALI J., ARKWRIGHT T. 2000: Investigation of UK Companies Practices in the Determination, Interpretation and Usage of Cost of Capital, The Journal of Interdisciplinary Economics 11, 303-319.

BREALEY R.A., MYERS S.C. 1991: Principles of Corporate Finance, McGraw-Hill, New York. BRUNER R.F., EADES K.M., HARRIS R.S., HIGGINS R.C. 1998: Best practices in estimating the cost of capital: Survey and synthesis, Financial Practice and Education, Spring/Summer, 13-28.

BYRKA-KITA K. 2008: Metody szacowania kosztu kapitału własnego. Teoria a praktyka, Rozprawy i Studia 689, Uniwersytet Szczeciński, 95-104.

BUGHIN J., COPELAND T.E. 1997: The Virtuous Cycle of Shareholder Value Creation, The McKinsey Quarterly 2, 156-167.

Business International Corporation 1997: Creating World-Class Financial Management, Strategies of 50 leading companies, Research Report 1-110, New York.

COPELAND T., WESTON J.F. 1998: Financial Theory and Corporate Policy, Addison-Wesley Publishing Company, USA.

FERLING R. 1994: Telling Academics What You Want to Know, Financial Executive, 10, 4.

GIRI V., SIVALA S. 2013: Dissecting India's Equity Risk Premium, How much to expect on your equity investments, Pricewaterhouse Coopers, India, June.

SANJEEV K. 2012: Real Estate Going Global India, Tax and legal aspects of real estate investments around the globe, Pricewaterhouse Coopers, India, June.

STEWART G. 1985: The Quest for Value: The EVA-TM Management Guide, Harper Business, Free Press, London. 


\title{
THE REVIEW OF RESEARCHES RELATED WITH THE PRACTICAL USE OF METHODS OF ESTIMATING THE COST OF CAPITAL IN DEVELOPED AND EMERGING ECONOMIES
}

\begin{abstract}
The main goal of the companies, increasing the value for the shareholder, requires awareness of the cost of capital. The ways of estimating the cost of capital in finance theory and business practice are still debatable. They are not transparent for all companies and for all economies. The aim of this article is to present the opinion of practitioners and a summary of its with theoretical views regarding to reliable calculation of the cost of capital. Particular emphasis is placed on the CAPM and the various parameters of this model.
\end{abstract}

Key words: cost of capital, CAPM, risk-free rate, market yield 